\title{
DEVELOPMENT OF DRYING SCHEDULE OF SUPERIOR AND CONVENTIONAL TEAK WOOD OF TEN YEARS-OLD PLANTED IN BLORA, CENTRAL JAVA
}

\author{
TOMY LISTYANTO*, YUSUF SETIA DARMAWAN, RINI PUJIARTI, \\ FANNY HIDAYATI, GANIS LUKMANDARU, \& JOKO SULISTYO
}

\author{
Department of Forest Product Technology, Faculty of Forestry, Gadjah Mada University \\ Jl. Agro No. 1 Bulaksumur, Sleman 55281 \\ *Email: tomy.listyanto@gadjahmada.edu
}

\begin{abstract}
The aims of this study were to investigate drying defect characteristics, to develop proper drying schedule, and to analyze the relationship between the developed drying schedule and its wood properties. This study used superior and conventional teak wood of ten years-old planted in Blora, Central Java. Sample from different axial positions (bottom and middle part) and different board thicknesses (20 mm and $40 \mathrm{~mm}$ ) were taken. Drying schedule was developed in accordance to Terazawa method, which dried the sample for $72 h$ at a temperature of $100{ }^{\circ} \mathrm{C}$. Initial moisture content, crack, collapse, and honeycombing were observed to determine the proper drying schedule. The developed drying schedule then was related to their characteristics, such origin of the seedling, thickness, density, and heartwood percentage. The proper scheduled was also applied in larger sample and evaluated. The results showed that there were five variations of drying schedule for superior and conventional teak wood. Chi square analysis indicated that the board thickness affect significantly on developing drying schedules. Boards with a thickness of $20 \mathrm{~mm}$ can be dried with an initial temperature of $70^{\circ} \mathrm{C}$, the wet bulb depression $7^{\circ} \mathrm{C}$, and the final temperature of $105^{\circ} \mathrm{C}$. Further, boards with a thickness of $40 \mathrm{~mm}$ should be dried with a softer drying schedule with an initial temperature of $60^{\circ} \mathrm{C}$, wet bulb depression temperature of $4^{\circ} \mathrm{C}$, and the final temperature of $85^{\circ} \mathrm{C}$. Application of the selected drying schedule was succeed without any significant defects.
\end{abstract}

Keywords: superior, teak, drying schedules, inferior, wood.

\section{INTISARI}

Tujuan dari penelitian ini adalah mengetahui karakteristik cacat pengeringan, skedul pengeringan yang sesuai, variasi ketebalan papan serta beberapa sifat kayunya terhadap skedul pengeringan. Penelitian ini menggunakan kayu jati prospektif unggul dan konvensional umur 10 tahun dari Blora, Jawa Tengah dengan letak aksial yang berbeda (pangkal dan tengah) serta ketebalan papan masing-masing $20 \mathrm{~mm}$ dan $40 \mathrm{~mm}$. Penyusunan skedul pengeringan menurut metode Terazawa, dengan pengeringan selama 72 jam pada suhu $100^{\circ}$ C. Parameter yang diamati yaitu kadar air awal, cacat retak, kolaps, dan honeycombing. Cacat yang terjadi digunakan untuk penyusunan skedul pengeringan. Skedul pengeringan selanjutnya diuji hubungannya dengan sumber asal bibit, ketebalan, berat jenis, dan persen kayu terasnya. Skedul pengeringan yang paling sesuai selanjutnya diujicoba dan dievaluasi. Berdasarkan hasil penelitian, diajukan lima skedul pengeringan. Hasil analisis chi square menunjukkan bahwa ketebalan papan memiliki hubungan signifikan terhadap variasi skedul pengeringan. Papan dengan ketebalan $2 \mathrm{~cm}$ dapat dikeringkan dengan suhu awal $70^{\circ} \mathrm{C}$, depresiasi bola basah $7^{\circ} \mathrm{C}$, dan suhu akhir $105^{\circ} \mathrm{C}$. Selanjutnya, papan dengan ketebalan $4 \mathrm{~cm}$ perlu dikeringkan dengan skedul yang lebih lunak dengan suhu awal $60^{\circ} \mathrm{C}$, depresiasi suhu bola basah $4^{\circ} \mathrm{C}$, dan suhu akhir $85^{\circ} \mathrm{C}$. Hasil uji aplikasi menunjukkan hasil yang memuaskan dengan cacat yang tidak signifikan.

Kata kunci: unggul, jati, skedul pengeringan, inferior, kayu. 


\section{INTRODUCTION}

Teak (Tectona grandis L.f) wood is one of the most important plantation species in Indonesia, especially in Java, due to its strength, natural durability and aesthetic qualities (Pandey and Brown, 2000). However, the gap between supply and demand of teak wood has been widening. Decreasing teak wood supply due to massive illegal logging in the last two decades contributed to reducing total teak wood production (Siswamartana, 2005). Teak tree breeding program in Indonesian has been developing to produce more productive teak trees, including in the State Forest Enterprise (PERHUTANI), which is the biggest forest company in Java. Superior clones of teak, which is called Jati Plus PERHUTANI, shows good performance on growth characteristics, such as diameter, height, stem form, compare to conventional one ( $\mathrm{Na}$ 'iem, 2000), therefore, has been selected and established in wider plantations area.

As the growth rate is increasing, it is possible to harvest or utilize the trees in the younger age. However, shorter rotations might show higher proportion of juvenile wood, reaction wood some inferior quality, very high growth stresses, and low dimensional stability (Maeglin, 1987; Mujumdar, 2014; Listyanto and Nichols, 2009; and Listyanto et al. 2010b). In addition, teak is also considered as wood with low permeability (Ahmed and Chun, 2011). These inferior wood quality become constraints for producing high quality wood products for more competitive markets.

Wood drying is an important step for preparing products that require the timber to be a stable state in use. One of the important factors in wood drying is proper drying schedule. Drying schedule can be defined as series of dry and wet-bulb temperatures that establish the temperature and relative humidity in a kiln and are applied at various stages of a drying process (Simpson, 1991). Even though there are various drying schedules for teak wood such as developed by Simpson (1996) and Listyanto et al. (2010a), however, those drying schedules may not be proper for wood with cut from younger teak trees, which show high portion of juvenile wood. For example, there are undesirable features in juvenile wood of Pinus spp., such as higher amount of compression wood and lower basic density that potentially cause problem with crook, bow, and collapse during higher temperature drying (Keey et al., 2000).

The proper schedule is important so that the drying stresses do not exceed the strength of the wood at any given temperature and moisture content, otherwise, the wood crack either on the surface or internally, or be crushed by forces that collapse the wood cells (Simpson, 1991). Wood Drying Working Party suggested to develop drying schedule to improve better drying quality (Vermaas, 1983) especially in tropical countries, which have many species variations (Simpson, 1992). One of the rapid methods to develop drying schedules was initiated by Terazawa (1965), which showed the satisfaction results to develop proper drying schedule (Ilic and Hillis, 1986; Jankowsky, 1992). Developing drying schedules should consider wood properties variations within a species (Boone et al., 1988). Density, heartwood percentages, lumber size play important role in developing drying schedule (Durand, 1985; Simpson, 1996). Different lumber thickness is also considered influence on developing drying schedule due to the severe moisture gradient between surface and centre specimen may occur during the process.

The aims of this study were to develop drying schedule of superior (clonal seed) and conventional (seedling seed) teak and to analyze the relationship 
between seed orchards (clonal and seedling seed) and drying schedule; the relationship between lumber thickness and developed drying schedule; and the relationship between developed drying schedule and its wood properties. Proper drying schedules were then applied to board with having higher length and were evaluated for their drying qualities. The selected drying schedules are important to company that will use woods which harvested from younger age, especially around ten years old.

\section{MATERIALS AND METHODS}

A total of twelve logs of superior and conventional teak of ten years old teak (Tectona grandis L.f.) harvested from plantation forest in Forest Management Unit Randublatung, in Blora, Central Java. A total of 34 samples in two different thicknesses, which were $20 \times 100 \mathrm{~mm}$ and $40 \times 100$ $\mathrm{mm}$ in width and thickness, and $300 \mathrm{~mm}$ in length, were cut from both superior and conventional teak wood. All specimens were dried in the oven with temperature of $103^{\circ} \mathrm{C}$ for $72 \mathrm{~h}$ in accordance to the method initiated by Terazawa (1965). The specimens were weighed and measured. Checks and collapse were investigated and measured. Honeycombing defects were observed by cutting in the middle part of the sample. Level of checks, collapse, and honeycombing were scaling based on Table 1 . The most severe defect was used for primary indicator to select initial temperature, wet bulb depression and final temperature (Table 2). Drying schedule was developed based on Table 3. The detailed procedure can be seen in Terazawa (1965) which was modified and adjusted by Jankowski (1992).

Specific gravity and heartwood percentages of each sample were also measured. Wood density was determined in accordance to BS 373 (1957). Specific gravity and heartwood percentage were classed based on statistical method in which equation was as follows :

$\mathrm{N}=1+3.3 \log \mathrm{n}$, where $\mathrm{N}$ is number of class and $\mathrm{n}$ is

total used sample.

The length of class was determined by dividing the distance between maximum and minimum value of parameters by the number of class. The relationship between type teak wood properties and

Table 1. Classification of defects based on Terazawa and modified by Jankowski .

\begin{tabular}{|c|c|c|c|c|}
\hline \multirow{2}{*}{ Level of defects } & \multicolumn{2}{|c|}{ Checks } & \multirow{2}{*}{$\begin{array}{c}\text { Collapse } \\
(\mathrm{A}-\mathrm{B})(\mathrm{mm})\end{array}$} & \multirow{2}{*}{ Honeycomb } \\
\hline & End checks (mm) & Surface check (mm) & & \\
\hline 1 & No check & No check & $0 \sim 0,3$ & No \\
\hline \multirow[t]{2}{*}{2} & $\mathrm{~L}<10$ & $\mathrm{~L}<50$ & $0,3 \sim 0,5$ & $1 \sim 2$ \\
\hline & $\mathrm{W}<0,8$ & $\mathrm{~W}<0.5$ & & \\
\hline \multirow[t]{2}{*}{3} & $\mathrm{~L}>10$ & $5<\mathrm{L}<100$ & $0,5 \sim 0,8$ & $3 \sim 4$ \\
\hline & $\mathrm{W}<0,8$ & $1<\mathrm{W}<1.5$ & & \\
\hline \multirow[t]{2}{*}{4} & $\mathrm{~L}<10$ & $\mathrm{~L}<150$ & $0,8 \sim 1,2$ & $5 \sim 7$ \\
\hline & $0.8<\mathrm{W}<1.5$ & $\mathrm{~W}<1.5$ & & \\
\hline \multirow[t]{2}{*}{5} & $\mathrm{~L}>10$ & $\mathrm{~L}>150$ & $1,2 \sim 1,8$ & $8 \sim 10$ \\
\hline & $0.8<\mathrm{W}<1.5$ & $\mathrm{~W}>1.5$ & & \\
\hline \multirow[t]{2}{*}{6} & $\mathrm{~L}>10$ & $\mathrm{~L}>150$ & $1,8 \sim 2,5$ & $>10$ \\
\hline & $\mathrm{W}<0.8$ & $\mathrm{~W}>1.5$ & & \\
\hline \multirow[t]{2}{*}{7} & $\mathrm{~L}>10$ & $\mathrm{~L}>150$ & $2,5 \sim 3,5$ & \\
\hline & $\mathrm{W}<0.8$ & $\mathrm{~W}>1.5$ & & \\
\hline \multirow[t]{2}{*}{8} & $\mathrm{~L}>10$ & $\mathrm{~L}>150$ & $>3,5$ & \\
\hline & $\mathrm{W}<0.8$ & $\mathrm{~W}>1.5$ & & \\
\hline
\end{tabular}

Note: $\mathrm{L}$ is length and $\mathrm{W}$ is Width. 
Table 2. Classitication of initial temperature, wet bulb depression and tinal temperature based on level of checks, collapse and honeycombing based on Terazawa (1965).

\begin{tabular}{|c|c|c|c|c|c|c|c|c|c|}
\hline \multirow{2}{*}{ Type of defects } & \multirow{2}{*}{$\begin{array}{l}\text { Drying schedule } \\
\left({ }^{\circ} \mathrm{C}\right)\end{array}$} & \multicolumn{8}{|c|}{ Grade of defects } \\
\hline & & 1 & 2 & 3 & 4 & 5 & 6 & 7 & 8 \\
\hline \multirow[t]{3}{*}{ Checks } & Initial temperature & 70 & 65 & 60 & 55 & 53 & 50 & 47 & 45 \\
\hline & Wet bulb depression & 6.5 & 5.5 & 4.3 & 3.6 & 3.0 & 2.3 & 2.0 & 1.8 \\
\hline & Final temperature & 95 & 90 & 85 & 83 & 82 & 81 & 80 & 70 \\
\hline \multirow{3}{*}{ Collapse } & Initial temperature & 70 & 66 & 58 & 54 & 50 & 49 & 48 & 47 \\
\hline & Wet bulb depression & 6.5 & 6.0 & 4.7 & 4,0 & 3.6 & 3.3 & 2.8 & 2,5 \\
\hline & Final temperature & 95 & 88 & 83 & 80 & 77 & 75 & 73 & 70 \\
\hline \multirow[t]{3}{*}{ Honeycombing } & Initial temperature & 70 & 55 & 50 & 49 & 48 & 45 & - & - \\
\hline & Wet bulb depression & 6.5 & 4.5 & 3.8 & 3.3 & 3.0 & 2.5 & - & - \\
\hline & Final temperature & 95 & 83 & 77 & 73 & 71 & 70 & - & - \\
\hline
\end{tabular}

Table 3. Drying schedule based on misture content

\begin{tabular}{ccccccccccc}
\hline Moisture & \multicolumn{8}{c}{ Step of temperature based on moisture content $\left({ }^{\circ} \mathrm{C}\right)$} \\
\cline { 2 - 10 } Content (\%) & 35 & 40 & 45 & 50 & 55 & 60 & 65 & 70 & 80 & 85 \\
\hline Green - 40 & 35 & 40 & 45 & 50 & 55 & 60 & 65 & 70 & 85 & 90 \\
$40-35$ & 35 & 40 & 45 & 50 & 55 & 60 & 65 & 75 & 90 & 100 \\
$35-30$ & 35 & 40 & 45 & 50 & 58 & 65 & 65 & 80 & 95 & 110 \\
$30-25$ & 35 & 43 & 48 & 55 & 63 & 70 & 70 & 85 & 100 & 120 \\
$25-20$ & 38 & 48 & 53 & 60 & 68 & 75 & 80 & 95 & 110 & 120 \\
$20-15$ & 40 & 53 & 58 & 65 & 70 & 80 & 85 & 105 & 120 & 120 \\
$15-10$ & 45 & 60 & 65 & $70-80$ & $70-80$ & $80-90$ & $85-90$ & 105 & 120 & 120 \\
$<10$ & 55 & 60 & 65 & $70-80$ & $70-80$ & $80-90$ & $85-90$ & 105 & 120 & 120 \\
\hline
\end{tabular}

the developed drying schedule was analyzed by chi square test. Selected schedules were applied in longer samples $(600 \mathrm{~mm})$ and 12 replications. The level of checks, collapse, honeycomb and warping were observed as parameters of drying quality to evaluate the selected schedule.

\section{RESULTS AND DISCUSSION}

The results showed that there are various specific gravity, heartwood percentage, level of checks, collapse and honeycomb of superior and conventional teak with the thickness of 20 and $40 \mathrm{~mm}$ (Table 4). Based on the Table 4, there were five variations of drying schedules for superior and conventional teak lumber. However, the most recommended drying schedule for teak lumber for both from superior and conventional teak was the schedule with an initial temperature of $70^{\circ} \mathrm{C}$, wet bulb depression $7^{\circ} \mathrm{C}$ (Relative Humidity 69\%) and final temperature $105^{\circ} \mathrm{C}$. The detailed drying scheduled is presented in Table 5. This schedule is more severe than drying schedule of teak developed by Boone et al. (1988) and drying schedules of teak developed by Listyanto et al. (2010b). Therefore, application with this drying schedule cause more rapid drying with minimum degrade compare to that developed by Boone (1988) and Listyanto et al. (2010b). The drying schedule can be set up more severe because the lumber showed insusceptibility from defects such as checks and collapse. The insusceptibility might be due to the better moisture diffusion during drying process, which reduces the 
different moisture distribution between surface and inside part. Rapid drying is important to reduce required energy and production cost, which increase economical benefit.

Chi square analysis indicate that lumber thickness has significant relationship with drying schedule $(\lambda=$ 23 , df $=4, \alpha=0.05)$. The percentage of the drying samples that distribute in different level of the drying schedule due to different lumber thickness can be seen in Figure 1. Generally, drying schedule of teak lumber with thickness of $20 \mathrm{~mm}$ is more severe than that of $40 \mathrm{~mm}$. The suggested schedule of teakwood with thickness of $40 \mathrm{~mm}$ is the schedule with an initial temperature of $60^{\circ} \mathrm{C}$, wet bulb depression $4^{\circ} \mathrm{C}$ (Relative Humidity 56\%) and final temperature $85^{\circ} \mathrm{C}$. The detailed drying schedules can be seen in Table 6 and 7. Therefore, teak lumber was not allowed to be set up more severe because the higher percentage of the sample susceptible with checks and collapse (Terazawa et al., 1984).

It is important to investigate the relationship between developed drying schedule and wood properties. Specific gravity and heartwood percentage are part of wood properties, which might

Table 4. Table of specific gravity, heartwood percentage, level of checks, collapse and honeycomb of superior and conventional teak with the thickness of 20 and $40 \mathrm{~mm}$.

\begin{tabular}{|c|c|c|c|c|c|c|c|}
\hline \multirow{2}{*}{ Seed Origin } & \multirow{2}{*}{ Thickness } & \multirow{2}{*}{ Replication } & \multirow{2}{*}{$\begin{array}{l}\text { Specific } \\
\text { gravity }\end{array}$} & \multirow{2}{*}{$\begin{array}{c}\text { Heartwood } \\
\text { Percentage }(\%)\end{array}$} & \multicolumn{3}{|c|}{ Level of Defects } \\
\hline & & & & & Checks & Colaps & Honeycomb \\
\hline \multirow[t]{16}{*}{ Superior } & \multirow[t]{8}{*}{$20 \mathrm{~mm}$} & 1 & 0.51 & 9.59 & 1 & 1 & 1 \\
\hline & & 2 & 0.50 & 9.49 & 1 & 1 & 1 \\
\hline & & 3 & 0.49 & 11.97 & 1 & 1 & 1 \\
\hline & & 4 & 0.55 & 11.84 & 1 & 1 & 1 \\
\hline & & 5 & 0.51 & 14.6 & 1 & 1 & 1 \\
\hline & & 6 & 0.52 & 7.23 & 1 & 1 & 1 \\
\hline & & 7 & 0.52 & 7.18 & 1 & 1 & 1 \\
\hline & & 8 & 0.53 & 24.18 & 1 & 1 & 1 \\
\hline & \multirow[t]{8}{*}{$40 \mathrm{~mm}$} & 1 & 0.51 & 13.16 & 1 & 1 & 1 \\
\hline & & 2 & 0.5 & 13.12 & 3 & 1 & 2 \\
\hline & & 3 & 0.49 & 14.38 & 3 & 1 & 1 \\
\hline & & 4 & 0.55 & 12.1 & 3 & 1 & 1 \\
\hline & & 5 & 0.51 & 8.44 & 1 & 1 & 1 \\
\hline & & 6 & 0.52 & 9.59 & 1 & 1 & 2 \\
\hline & & 7 & 0.52 & 13.23 & 2 & 1 & 1 \\
\hline & & 8 & 0.53 & 25.4 & 3 & 1 & 1 \\
\hline \multirow[t]{16}{*}{ Conventional } & \multirow[t]{8}{*}{$20 \mathrm{~mm}$} & 1 & 0.47 & 61.54 & 1 & 1 & 1 \\
\hline & & 2 & 0.5 & 57.13 & 1 & 2 & 2 \\
\hline & & 3 & 0.57 & 64.87 & 1 & 2 & 1 \\
\hline & & 4 & 0.5 & 57.51 & 1 & 1 & 1 \\
\hline & & 1 & 0.54 & 45.23 & 1 & 1 & 1 \\
\hline & & 2 & 0.57 & 40.69 & 1 & 1 & 1 \\
\hline & & 3 & 0.51 & 64.58 & 1 & 1 & 1 \\
\hline & & 4 & 0.5 & 48.1 & 1 & 1 & 1 \\
\hline & \multirow[t]{8}{*}{$20 \mathrm{~mm}$} & 1 & 0.58 & 76.68 & 3 & 1 & 1 \\
\hline & & 2 & 0.51 & 85.65 & 2 & 1 & 2 \\
\hline & & 3 & 0.48 & 97.05 & 3 & 1 & 1 \\
\hline & & 4 & 0.51 & 85.06 & 3 & 1 & 1 \\
\hline & & 5 & 0.64 & 50.82 & 3 & 1 & 1 \\
\hline & & 6 & 0.51 & 37.69 & 3 & 1 & 1 \\
\hline & & 7 & 0.51 & 25.33 & 2 & 1 & 1 \\
\hline & & 8 & 0.49 & 38.19 & 3 & 1 & 1 \\
\hline
\end{tabular}


Table 5. Five variation of drying schedule for superior and conventional teak.

\begin{tabular}{ccccc}
\hline \multirow{2}{*}{ No } & Schedule Code & \multicolumn{3}{c}{ Drying schedule parameters } \\
\cline { 3 - 5 } & $\begin{array}{c}\text { Initial Temperature } \\
\left({ }^{\circ} \mathrm{C}\right)\end{array}$ & $\begin{array}{c}\text { Wet Bulb Depression } \\
\left({ }^{\circ} \mathrm{C}\right)\end{array}$ & $\begin{array}{c}\text { Final Temperature } \\
\left({ }^{\circ} \mathrm{C}\right)\end{array}$ \\
\hline 1 & S1 & 55 & 3.5 & 80 \\
2 & S2 & 60 & 4 & 85 \\
3 & S3 & 65 & 5 & 90 \\
4 & S4 & 66 & 7 & 88 \\
5 & S5 & 70 & 7 & 105 \\
\hline
\end{tabular}

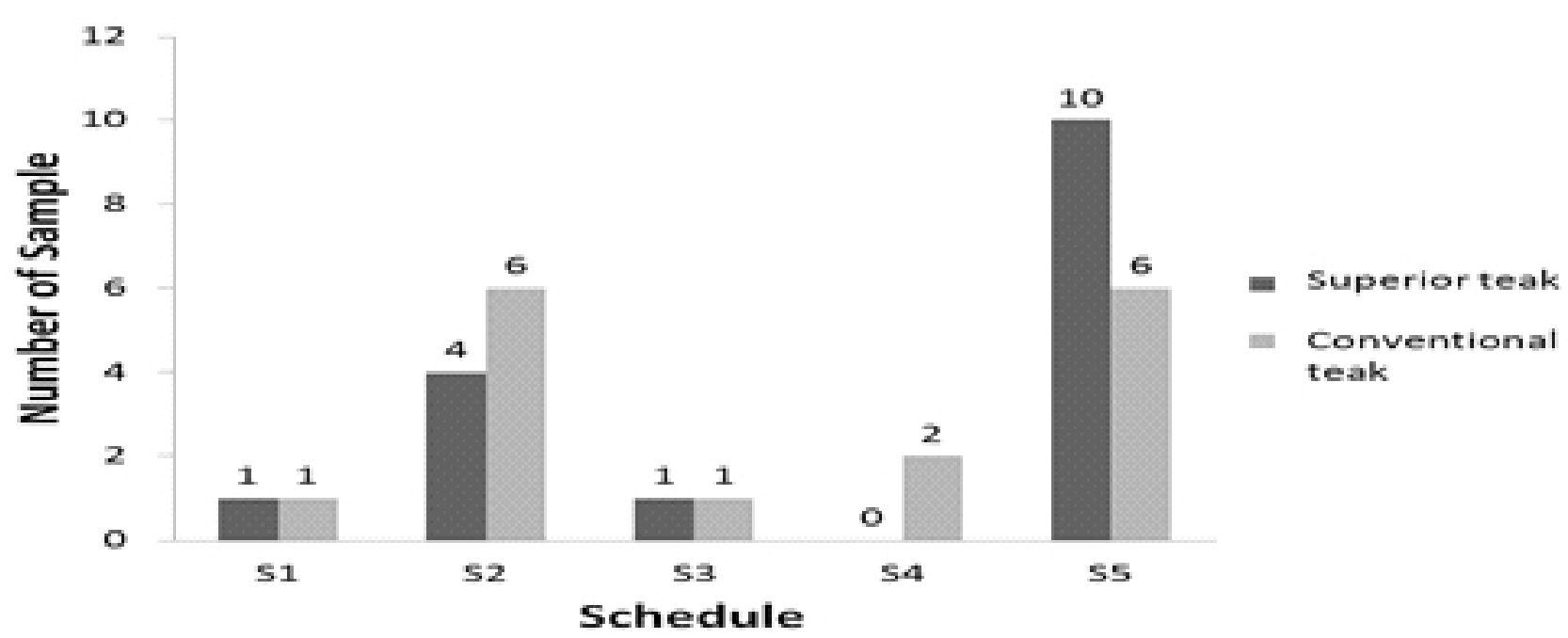

Fig. 1 Distribution of schedule groups of superior and conventional teak wood

Table 6. Recommended drying schedule for teak with the thickness of $20 \mathrm{~mm}$

\begin{tabular}{ccccc}
\hline MC $(\%)$ & Dry bulb $\left({ }^{\circ} \mathrm{C}\right)$ & Wet bulb depression $\left({ }^{\circ} \mathrm{C}\right)$ & Relative humidity $(\%)$ & EMC $(\%)$ \\
\hline Green-30 & 70 & 7 & 63 & 71 \\
$30-28$ & 80 & 10 & 70 & 64 \\
$28-26$ & 85 & 14 & 71 & 54 \\
$26-24$ & 85 & 20 & 65 & 41 \\
$24-22$ & 95 & 25 & 70 & 30 \\
$22-20$ & 95 & 30 & 65 & 27 \\
$20-18$ & 105 & 30 & 75 & 30 \\
$18-16$ & 105 & 30 & 75 & 30 \\
$16-14$ & 105 & 30 & 75 & 30 \\
$14-12$ & 105 & 30 & 75 & 30 \\
Equalizing and conditioning & & & \\
\hline
\end{tabular}

Note: $\mathrm{MC}=$ moisture content, $\mathrm{EMC}=$ equilibrium moisture content 
Table 7. Recommended drying schedule for teak with the thickness of $40 \mathrm{~mm}$

\begin{tabular}{ccccc}
\hline MC (\%) & $\begin{array}{c}\text { Dry Bulb } \\
\left({ }^{\circ} \mathrm{C}\right)\end{array}$ & $\begin{array}{c}\text { Wet bulb depression } \\
\left({ }^{\circ} \mathrm{C}\right)\end{array}$ & $\begin{array}{c}\text { Relative Humidity } \\
(\%)\end{array}$ & EMC (\%) \\
\hline $40-30$ & 60 & 4 & 56 & 81 \\
$30-28$ & 70 & 5.5 & 64.5 & 77 \\
$28-26$ & 70 & 8 & 62 & 68 \\
$26-24$ & 75 & 13 & 62 & 54 \\
$24-22$ & 75 & 17 & 58 & 43.5 \\
$22-20$ & 75 & 21 & 54 & 38 \\
$20-18$ & 80 & 25 & 55 & 30 \\
$18-16$ & 80 & $25-30$ & $50-55$ & 30 \\
$16-14$ & $80-90$ & $25-30$ & $55-60$ & 30 \\
$14-12$ & $80-90$ & $25-30$ & $55-60$ & 30 \\
Equalizing and conditioning & & & \\
\hline
\end{tabular}

Note: $\mathrm{MC}=$ moisture content, $\mathrm{EMC}=$ equilibrium moisture content

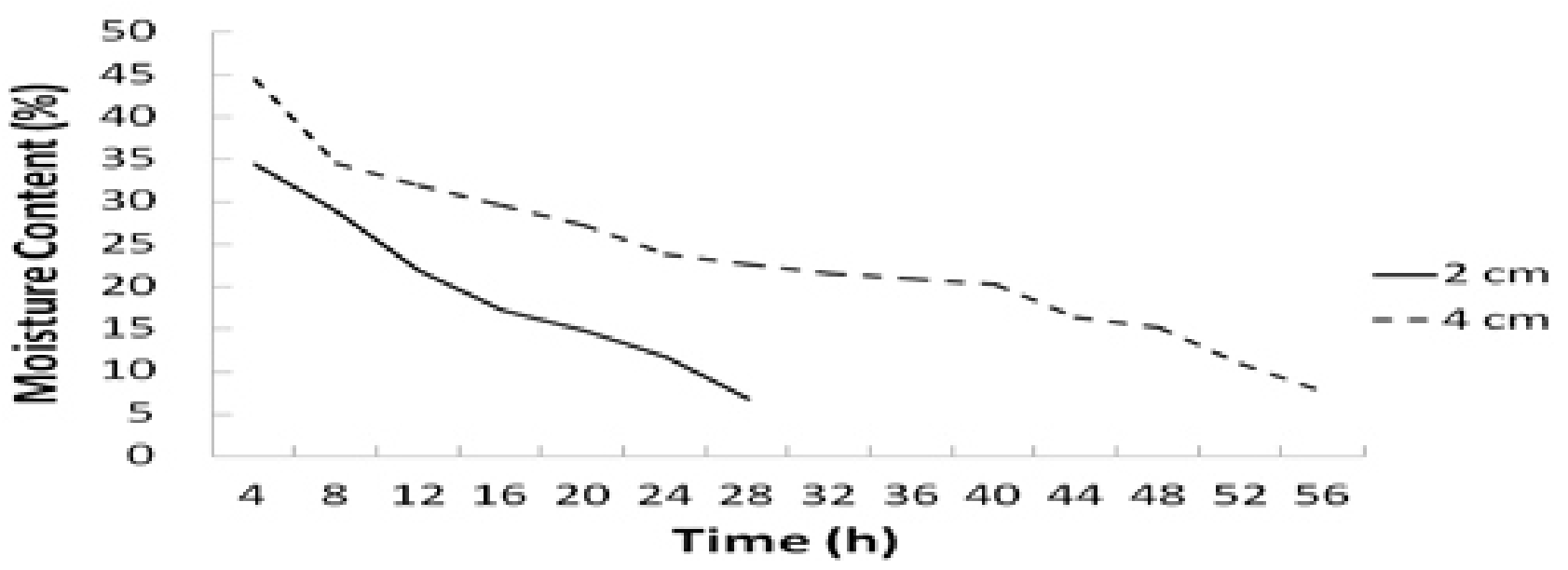

Fig.2. Drying rate of teak lumber with two different thickness.

have important role on developing drying schedule. In this study, the variation of specific gravity was between 0.46 and 0.65 while heartwood variation was between $7.2 \%$ and $97 \%$. However, this study showed that there is no significant relationship $(\lambda=$ $20, \mathrm{df}=20, \alpha=0.05)$ between developed drying schedule and both wood properties. Therefore, it can be stated that teak wood lumber with variation of specific gravity and heartwood percentage similar with the range in this study are allowed to put in one kiln drying with the schedule level of five. This result corresponds to the results by Listyanto (2010a) but contrary with the study of Zhang et al. (1996) and
Taghiyari et al. (2014) that higher density should be separated with the lower density in drying process because of different level of drying rate and defects. Changing of specific gravity in this study was not enough as important factor affecting developed drying schedule.

The application test of suggested drying schedule for teakwood with the thickness of 20 and $40 \mathrm{~mm}$ showed that the drying rate of lumber with thickness of $20 \mathrm{~mm}$ was higher than that of $40 \mathrm{~mm}$ (Figure 2). The level of checks, collapse, honeycomb and warping, were also fine (Table 8 ). Subsequently, it is 
Table 8. Drying rate and defects of teak lumber with two different thicknesses.

\begin{tabular}{lccccccc}
\hline & \multirow{2}{*}{$\begin{array}{c}\text { Drying rate } \\
(\% / \mathrm{h})\end{array}$} & Cupping & Bowing & Twisting & \multicolumn{3}{c}{ Check } \\
\cline { 6 - 8 } & & & & & End check & Surface & Split \\
\hline $2 \mathrm{~cm}$ & 1.39 & 1 & $1-2$ & $1-2$ & 0 & 0 & 0 \\
$4 \mathrm{~cm}$ & 0.7 & 1 & $1-2$ & $1-2$ & 0 & $1-2 \mathrm{~cm}$ & 0 \\
\hline
\end{tabular}

recommended that the suggested developed drying schedule could be used for both superior and conventional teak with certain thickness lumber.

\section{CONCLUSIONS}

There were five variations of drying schedule for superior and conventional teak wood. Chi square analysis indicated that the board thickness affects significantly on developing drying schedules. Boards with a thickness of $20 \mathrm{~mm}$ can be dried with an initial temperature of $70{ }^{\circ} \mathrm{C}$, the wet bulb depression $7^{\circ} \mathrm{C}$, and the final temperature of $105{ }^{\circ} \mathrm{C}$. Meanwhile, boards with a thickness of $4 \mathrm{~cm}$ should be dried with a softer drying schedule with an initial temperature of $60{ }^{\circ} \mathrm{C}$, wet bulb depression temperature of $4{ }^{\circ} \mathrm{C}$, and the final temperature of $85{ }^{\circ} \mathrm{C}$. Application of the suggested drying schedule was succeed without any significant defects.

\section{ACKNOWLEDGEMENTS}

This work was supported by PUPT Universitas Gadjah Mada Grant no. 115/LPPM/2015 (DIKTI). The authors thank Sugi Purwanta (R \& D Perum Pehutani) and Head and staff of Forest Management Unit Randbulatung Perum Perhutani for providing the logs used in this study.

\section{REFERENCES}

Ahmed SA \& Chun SK. 2011. Permeability of Tectona grandis L.f as affected by wood structure. Wood Science and Technology 45, 487-500.

Boone RS, Kozlik CJ, Bois PJ, \& Wengert EM. 1988. Dry Kiln Schedules for Commercial Woods: Temperate and Tropical Forest Products Laboratory. United States Department of Agriculture, Madison, Wiconsin.

Bristish Standard Institute. 1957. British Standard (BS) 373:1957: Methods of Testing Small Clear Specimens of Timber. British Standard Institution, London. 22.

Durand PY. 1985. Contribution to the study of determination tables of drying-physical properties of wood. Tropical Timber and Forest 207, 63-78.

Hidayati F, Ishiguri F, Iizuka K, Makino K, Marsoem NS, Yokota S. 2014. Among-clone variations of anatomical characteristics and wood properties in Tectona grandis planted in Indonesia. Wood and Fiber Science 46, 385-393.

Keey RB, Langrish TAG, \& Walker JCF. 2000. The Kiln Drying of Lumber. Springer, Berlin.

Ilic J \& Hillis WE. 1986. Prediction of collapse in dried eucalypts wood. Holzforschung 40,109-112.

Jankowsky IP. 1992. A screening to select kiln schedules. Piracicaba 2, 20-24.

Listyanto T \& Nichols JD. 2009. A review of relationships between wood quality and silvicultural practices. Jurnal Ilmu Kehutanan 3(2), 116-126.

Listyanto T, Glencross KS, Nichols JD, Schoer L \& Harwood C. 2010a. Performance of eight eucalypt species and interspecific hybrid combinations at three sites in northern New South Wales, Australia. Australian Forestry 73(1), 47-52. 
Listyanto T, Lukmandaru G, Pramadya C, Siswanto D, \& Hattori N. 2010b. Relationship between wood properties and developed drying schedule of inferior teak (Tectona grandis L.f) and mahogany (Swietenia macrophylla King). Wood Research Journal 1, 83-88.

Maeglin R. 1987. Juvenile wood, tension wood, and growth stress effects on processing hardwood. In: Proceedings of the $15^{\text {th }}$ Annual Hardwood Symposium of the Hardwood Research Council. Memphis, TN.

Mujumdar A S. 2014. Handbook of Industrial Drying. $4^{\text {th }}$ Edition. CRC Press, Boca Raton.

Na iem M. 2000. Early performance of clonal test of teak in. In:Proceeding of $3 r d$ Regional Seminar on Teak. Potentials and Opportunities in Marketing and Trade of Plantation Teak: Challenge for the Millenium. Yogyakarta. 271-275.

Pandey D \& Brown C. 2000. Teak: A global review. Unasylva 51(201), 3-13.

Simpson WT. 1991. Dry Kiln Operator's Manual. United States Department of Agriculture, Forest Service, Forest Products Laboratory, Madison, Wisconsin. 274.

Simpson WT. 1992. Drying technology issues in tropical countries. Proceeding of Forest Product International Union of Forestry Research Organizations. IUFRO, Nancy, France. 497-507.

Simpson WT. 1996. Method to estimate dry-kiln schedules and species groupings; Tropical and temperate hardwoods. Forest Products Laboratory, USDA. 57.

Siswamartana S. 2005 Ups and downs of teak forest management in Indonesia. In: Proceeding of the International Conference on Quality Timber Products of Teak From Sustainable Forest Management. Peechi, India. 63-67.

Taghiyari HR, Habibbzade S, \& Tari SMM. 2014. Effects of wood drying schedules on fluid flow in Paulownia wood. Drying Technology 32(1), 89-95.

Terazawa S. 1965. Methods for easy determination of kiln drying schedules of wood. Japan Wood Industry 20(5), 216-226. (In Japanese).

Terazawa S, Kobayashi T, \& Hadi YS. 1984. Drying characteristics of Sulawesi woods. Bulletin of the Nagoya University Forests 8, 151-167.

Vermaas HF. 1983. Synopsis of wood drying working party session. Proceeding of IUFRO
Division 5 Conference: Wood Drying Party. Madison. 5-6.

Zhang Y, Oliveira L, \& Avramidis S. 1996. Drying characteristics of hem-fir square as affected by species and basic density presorting. Forest Products Journal 46(2), 44-50. 